\title{
Political Brands: Can Parties Be Distinguished by their Online Brand Personality?
}

Authors: Rutter R, Hanretty C and Lettice F.

\section{Journal of Political Marketing}

\begin{abstract}
This paper investigates whether or not five English political parties are differentiating themselves based on the brand personality they are communicating through their websites. The relative brand positions of five English political parties are analysed using Aaker's brand personality scale. The text from each party website is analysed using content analysis and a dictionary-based tool. The results are plotted in relation to one another on a correspondence analysis map. We find that the two main dimensions on which parties' brand personalities differ relate to the trade-offs between communicating Competence and communicating Sincerity, and between communicating Sophistication and communicating Ruggedness. We find that parties' brand personalities are distinctive, with the exception of the Green party, and that the position of one party, the United Kingdom Independence Party, is particularly distinctive. Our research uses Aaker's existing framework for thinking about brand personalities, rather than creating a new framework for politics. By using an existing framework, we are able to use tools developed in other disciplines, and show their usefulness for the study of political marketing.
\end{abstract}

Keywords: political marketing, brand personality, brand differentiation, political brands 


\section{Introduction}

Several concepts previously used exclusively to refer to commercial companies are now often used to describe political parties (see, for example, Katz and Mair (1995) on cartel parties). The concepts of the brand, and of brand personality, are two such concepts. Branding, and the communication of brand identity, help voters understand and identify with political parties emotionally and symbolically (White and Chernatony 2002, Urde 1999). Although the use of branding has been criticised for potentially narrowing the political agenda (Smith 2009) and for misapplying commercial concepts to a non-commercial sphere (Harris and Lock 1996), both parties and individual politicians have long understood the importance of branding and brand personality in electoral campaigning (Benn 1994, 2002).

The increased use of the concepts of the brand and brand personality, in both commercial and electoral contexts, has gone hand in hand with increased attention to the characterisation and measurement of brand personality. The seminal work in this field is Aaker's (1997) work on brand personality. Aaker combined human dimensions of personality with other marketing scales to create sets of human characteristics associated with a brand. The anthropomorphisation of brands in general helps consumers emotionally engage with products independent of their technical characteristics (Patterson, Khogeer, and Hodgson 2013), and the construction of a brand personality for political parties in particular helps voters (who may be rationally ignorant of the issues, or of policy debates: Popkin (1994)) by providing them with a useful heuristic device . As a result, researchers have begun to use the concepts of brand image or brand personality in studying political campaigning (Guzmán and Sierra 2009, Smith 2001, 2009, Rutter and Lettice 2014), so much so that the approach is now considered uncontroversial (French and Smith 2010).

Despite this, gaps in the literature remain. One such gap is the gap between brand personality as something which is perceived by individuals, and brand personality as something actively produced by parties. The campaign material produced by parties is an important source of information about the means by which parties communicate brand personality to voters. Yet the literature on brand 
personality in political marketing has not yet made the same move as the brand personality literature more generally, which has begun to focus on the communication of brand personality through written text (Opoku 2006, Opoku et al. 2007, Opoku, Abratt, and Pitt 2006, Haarhoff and Kleyn 2012). The analysis of written texts produced by parties and in particular, party manifestos has been extremely useful in the study of party politics more broadly (Budge 2001, Gabel and Huber 2000, Slapin and Proksch 2008), and the literature on political brands stands to benefit by making greater use of this resource.

A second gap concerns the potential of brand personality analyses to reliably discriminate between political parties, particularly in a multiparty setting. Existing tests of Aaker's framework in the political context have concentrated on the ability of a number of underlying traits to 'explain' ratings on a number of specified personality characteristics (Smith 2009). This is slightly different from the ability of those traits to discriminate between the objects to which they apply. Although good measures will typically have both a robust factor structure and good discrimination between brands, it may be that where brand personalities are ill-defined, or poorly communicated, brand personality may not be useful for discriminating between parties. ${ }^{1}$

This paper therefore deploys a new tool - a dictionary-based analysis of parties' written communications to analyse the distinctiveness of the communicated brand personalities of five UK political parties: the Labour Party, the Conservative Party, the Liberal Democrats, the Green Party, and the United Kingdom Independence Party. We look at the texts produced by these parties for their websites, constructing five large corpora comprising in total over one million words. We analyze these corpora using the dictionary-based approach pioneered by Opoku (2006), which allows us to identify communicated brand personality by the relative frequency of the words used on each party's website. We find that four of the five parties can be distinguished from each other, with two parties (the Liberal Democrats and the United Kingdom Independence Party) maximally

1 Indeed, as we shall later show, this holds for the Green Party in the UK. 
distinctive, and one party (the Green Party) not sufficiently distinctive in virtue of its limited communication.

The key aims and contributions of this paper are therefore to demonstrate that the brand personality being communicated by party political websites can be measured, using Aaker's (1997) brand personality framework and Opoku's (2006) dictionary based brand personality tool. In addition, we aim to show that brand personality can be used to distinguish between the five main British political parties, demonstrating the usefulness of Aaker's (1997) brand personality theory for the study of political parties and political marketing.

We begin our analysis by reviewing the existing literature on branding and brand personality within political contexts, and on text analysis within political science. We then move on to describe the methods we used to construct our corpora, and those used to analyse the corpora and produce party positions. We conclude by discussing the significance of our findings for the study of British politics and for political marketing, as well as their broader societal relevance.

\section{Previous Literature}

In this section, we discuss two broad areas: research into branding and brand personality, and its measurement; and research on the role of branding in political competition. We bring these two areas together by focusing on an area of common concern - the communication of brand personality through written text.

\section{The concept and measurement of brand personality}

The concept of 'brand personality' builds on the concept of the brand, and as such, only began to emerge in the late seventies with the increasing emphasis on immaterial, brand-based features of products. As brand personality has evolved today, it represents the character of the brand as if it were a person, or anthropomorphisation (Patterson, Khogeer, and Hodgson 2013). It involves 
attributing human characteristics to the brand, and is a way to create uniqueness by reinforcing those human psychological values to which consumers relate, beyond mere performance and functionality. Therefore, brand personality is the requirement for a relationship between consumers and brands. When brands are anthropomorphised, consumers will not only perceive them, but also have a relationship with them. A dominant model of this phenomenon exists today, which was originally produced by Jennifer Aaker (1997) and has been adopted by a significant number of studies.

The measurement of brand personality has evolved within academia for the last 40 years. Originally, studies were more focused upon product personality and the level of congruence between consumer identity and the product (Birdwell 1968, Dolich 1969). Malhotra (1981) built upon these early theoretical concepts, advocating brand personality scales and the need to ensure validity. He further outlined a procedure of scale development for self-perspective, person and product concepts, which have been used within subsequent studies (Aaker 1997). Although different ways of measuring brand personality have been proposed (e.g. by Sweeney and Brandon (2006), Bosnjak, Bochmann, and Hufschmidt (2007), Kuenzel (2009), Heine (2009) and Lee, Soutar, and Quintal (2010)), the most notable brand personality framework used today is that developed by Aaker (1997). Aaker's (1997) framework of brand personality was constructed based upon the "Big Five" human dimensions of personality, adapted for use in the context of brands through filtration and use of other marketing scales. Aaker's scale is designed specifically within the context of Western brands, and is the most widely adopted within the literature. It has been rigorously tested and validated, resulting in known limitations (Azoulay and Kapferer 2003). Although Geuens, Weijters, and De Wulf (2009) developed a framework of brand personality to address the validity and limitations of Aaker's framework, only a small number of studies have adopted the scale. It has, therefore, yet to be thoroughly validated and tested. In contrast, Aaker's model of brand personality was the first robust, reliable and valid framework developed to measure 
brand personality, and it has served as a foundation for the majority of further studies (Clemenz, Brettel, and Moeller 2012).

Aaker's (1997, p.347) brand personality framework enables academics to describe and measure five dimensions of the personality aspect of a brand and is defined formally as "the set of human characteristics associated with a brand". These dimensions are sincerity, excitement, competence, sophistication and ruggedness. As is the case with many brand personality constructs, traits were utilised from other personality scales. This included both psychological personality scales (204 traits) and personality scales used by marketers (113 traits from both academics and practitioners), whilst also including a dimension of original qualitative research (295), resulting in 309 nonredundant personality traits. These traits were reduced to 114 , and in subsequent testing to 42 traits, which were then thoroughly tested for reliability and validity. Most research which has adopted Aaker's framework has asked consumers to rate brands against the traits and five dimensions, usually with a 7-point Likert scale (Jamal and Goode 2001, Sirgy et al. 1997, Sirgy and Su 2000).

Earlier work on measuring brands and brand value was before many organisations had developed an internet presence or online marketing channels. Since then the interest in online brands has increased. Indeed, in 2010, online marketing spend in the UK surpassed that spent on television (Heinze and Fletcher 2011). The role of online brands, as complementary to traditional brands (Sääksjärvi and Samiee 2011, Christodoulides et al. 2006), is important to help consumers to navigate through the large amount of information which is now available to them (Ward and Lee 2000).

The large number of websites, and the fact that the web remains primarily a written medium, means that brand personality in the context of websites is often measured differently. Whereas Aaker recruited individual respondents to evaluate brands against a list of adjectives, Opoku (2006) generated a list of keywords designed to correspond to Aaker's five dimensions, and which could be used to assess the brand personality of a website using the text of the website itself, and eliminating 
the need for human evaluators. As such, Opoku's approach measures the brand personality as communicated by a website, rather than the brand personality as perceived by potential consumers. This method has been successfully applied to websites in a variety of sectors, and is the method we use in analyzing political party websites in our research.

The use of keyword or dictionary-based text analysis has become relatively common in the study of politics. One common set of keyword lists, Linguistic Inquiry, and Word Count (LIWC) has been used to examine levels of cognitive complexity amongst candidates for office (Slatcher et al. 2007) and justices on the Supreme Court of the United States (Owens and Wedeking 2011). Insofar as it seeks to recover information specified a prior, dictionary based analysis is opposed to other more complex models which seek to recover dimensions of textual variation present in the data (Slapin and Proksch 2008).

Within the study of brand personality, Opoku, Abratt, and Pitt (2006) built on Aaker's work by compiling a dictionary of synonyms which allows researchers to categorise textual content within dimensions of brand personality. Opoku, Abratt, and Pitt (2006) identified and then filtered the synonyms, removed ambiguous words, and the dictionary was then validated and verified within a series of empirical studies. In total the dictionary includes 1625 words, with each of the five dimensions having a similar proportion of synonyms. More specifically: 'Sincerity has $21 \%$ of all words listed; Excitement 17\%; Competence 20\%; Sophistication 21\%; and Ruggedness 21\%' (Opoku 2006). Opoku's brand personality dictionary currently stands as the only method to quantifiably assess brand personality via textual communications, within Aaker's five dimensions of brand personality. The method is unique in that the analysis provides a frequency count of dimensional synonyms within a text, which shifts the focus from the perception of brand personality by consumers, to what the organisations as brands are saying about themselves. 


\section{Brand and brand personality in politics}

The use of brand personality in political competition can be located within a broader debate about the factors weighing on electoral competition in the UK and more generally. Specifically, brand personality relates to the historic debate between positional and valence accounts of electoral choice.

Positional accounts of electoral choice can be traced back to the work of Anthony Downs, and in particular his 1957 book An economic theory of democracy (Downs 1957). Downs assumed two parties compete over a single policy dimension (often taken to be a left-right dimension), and alter position in order to maximize vote share. Under certain electoral systems, this account implies that parties should move to the position of the median voter, with no differentiation in the resulting policy offers.

Valence accounts of electoral choice developed as a response to Downsian accounts, and emphasized the importance of issues "that merely involve the linking of the parties with some condition that is positively or negatively valued by the electorate" (Stokes 1963, p.373). Common positive valence characteristics of candidates and parties include perceived competence, likeability, and consistency. Common negatively valued valence characteristics might include internal division, or being seen to be interested in office for its own sake.

The debate between positional and valence accounts of electoral choice is a long-running one, but more recent literature tends to place greater emphasis on valence characteristics. This is certainly true of research into electoral choice in the UK, which has focused particularly on evaluations of the leaders of the main parties, and on perceptions of economic competence, as key characteristics in determining voter choice (Clarke et al. 2011, Sanders et al. 2011).

There is a link between valence accounts of electoral choice, and brand personality, insofar as many valence characteristics can be considered as personality traits. (There is also a more general association between brands and voting choice, insofar as strong brands are more likely to be voted 
for, even controlling for positional and demographic factors: see Nielsen and Larsen (2014)). This is certainly true of two key characteristics, competence and sincerity, which form two factors in Aaker's (1997) model of brand personality, and which also feature frequently in accounts of electoral choice.

Understandably, the literature on trait voting has focused on the personality traits of candidates (Mattes and Milazzo 2014), or party leaders (Garzia 2013), rather than the traits of parties. Given that voters' perceptions of candidates' traits are always inferred from candidate actions, research has examined how candidates may craft the communication of specific personality traits as part of an electoral strategy. In particular, some research has suggested that candidates who signal traits not normally associated with their party benefit electorally (Hayes 2005), although research in the UK at the candidate level has not found any evidence for such "trait trespassing" (Shephard and Johns 2008).

Even if there is an advantage to selectively communicating such traits, some of the traits we discuss here cannot be strategically communicated. Candidates (and parties) cannot selectively communicate sincerity if this involves acting in insincere or disingenuous ways. This is a particular problem for parties which seek to professionalize their campaign operations. Certainly, parties' campaign materials do attempt to project positive personality traits such as competence. The Conservative Party's famous "Labour Isn't Working” campaign, designed by Saatchi \& Saatchi, can be interpreted as a successful attack on the Labour party's (economic) competence (Smith and Saunders 1990). Less successfully, the Conservative party's 2005 campaign slogan, 'Are you thinking what we're thinking?' attempted to project sincerity by highlighting the party's stance on immigration and benefits.

Almost all valence accounts rely on voters' evaluations of parties' traits, something which is also true of many positional accounts. Positional accounts, however, have been able to rely on text-based assessments of parties' positions, and in particular positions estimated on the basis of the manifestos 
produced by political parties. Whether through hand-coding (Budge 2001) or automated analysis (Slapin and Proksch 2008), the analysis of text can produce (more frequent) estimates of positions on many more dimensions than can be asked of voters.

This potential is shared by the dictionary-based analysis proposed by Opoku (2006). By applying this method, we can learn about traits not commonly asked about, such as ruggedness, sincerity and excitement. We can also learn about the degree to which any differences in these traits are communicated by parties. Whilst Smith (2009) found differences in the degree to which Labour and Conservative parties demonstrated different personality traits, it was not clear from that analysis whether the perception of those traits depended on recent (successful or unsuccessful) efforts by parties to communicate certain traits, or whether it instead depended on the parties' records over the longue durée, or on stereotypes transmitted in early political socialization. Analysis of how parties themselves communicate brand personality is therefore an interesting and necessary step.

\section{Methodology}

In the previous section, we discussed the potential for measuring the brand personality of different political parties through the text they produce. In this section, we outline the procedures we followed to harvest a large amount of text through parties' websites. We chose party websites because they are under the direct control of the party, provide a large amount of textual material, and because party websites are an increasingly common source of information for voters (Papagiannidis, Coursaris, and Bourlakis 2012), particularly for certain undecided voters (Karlsen 2010). As far as we are aware, this is the first analysis of the use of political party websites to communicate a particular brand personality, rather than (say) to offer campaigning tools (Gibson and Ward 2000) or to mobilize existing voters (Norris 2003).

First, starting with the main websites of the five parties considered here (http://www.labour.org.uk/; www.conservatives.com/; www.libdems.org.uk/; www.ukip.org/; www.greenparty.org.uk/) we 
downloaded all pages within the domain up to a link-depth of three, and isolated all parts of the web page which contained substantive content rather than formatting elements common to all pages. ${ }^{2}$ Sites were scraped on the $12^{\text {th }}$ February 2013 , but the content extended back several years. We stripped all HTML tags to create a plain-text corpora free of formatting and style information. We were then left with five corpora (one for each party) containing on average 217,000 words each.

Second, we counted the number of words in each document which featured on one of the five wordlists created by Opoku (2006). These word-lists contain words which are commonly used to express the five brand personality traits identified by Aaker (1997). On average, each word-list contains slightly more than three hundred words, or word-phrases, or word-stems. Examples of commonlyfound words, word-phrases, and word stems corresponding to each word-list are featured in Table 1

Table 1: Selected words from Opoku's brand personality dictionary

\begin{tabular}{|l|l|}
\hline Trait & Selected words \\
\hline Competence & Competent, guarantee, responsible, staunch, unshakable \\
\hline Sincerity & Authentic, affable, down-to-earth, heartfelt, realistic \\
\hline Sophistication & Celebrated, charismatic, distinguished, graceful \\
\hline Ruggedness & Challenge, endeavour, rigorous, tough, unrestrained \\
\hline Excitement & Bold, courageous, fresh,inventive, stirring, \\
\hline
\end{tabular}

To ensure robustness, the automated counting process was carried out twice: once, using WordStat, and once, using a short Perl script. The results were similar, differing only concerning minor

2 This was done in a semi-automated fashion, using software to follow all links, and supplying the software with a human-generated list of the HTML elements known to contain content based on the website design template used for each site. 
differences in word-stemming or in the treatment of compound phrases. The raw counts of these words are shown in Table 2(a).

Table 2 (a): Counts of words corresponding to each trait

\begin{tabular}{|c|c|c|c|c|c|c|}
\hline Party & $\begin{array}{l}\text { "Competence" } \\
\text { words }\end{array}$ & $\begin{array}{l}\text { "Excitement" } \\
\text { words }\end{array}$ & \begin{tabular}{|l|} 
"Rugged" \\
words
\end{tabular} & $\begin{array}{l}\text { "Sincerity" } \\
\text { words }\end{array}$ & $\begin{array}{l}\text { "Sophistication" } \\
\text { words }\end{array}$ & $\begin{array}{l}\text { Total } \\
\text { word } \\
\text { count }\end{array}$ \\
\hline Conservative & 2194 & 1997 & 804 & 1520 & 738 & 894,417 \\
\hline Labour & 698 & 794 & 271 & 511 & 122 & 326,588 \\
\hline $\begin{array}{l}\text { Liberal } \\
\text { Democrat }\end{array}$ & 408 & 425 & 60 & 202 & 135 & 231,161 \\
\hline UKIP & 1967 & 2917 & 687 & 3428 & 728 & $1,074,372$ \\
\hline Green & 140 & 114 & 50 & 113 & 27 & 61,891 \\
\hline
\end{tabular}

These counts can also be expressed as percentages of the total number of words expressing any trait. These proportions are shown in Table 2(b). 
Table 2(b): Trait words expressed as a percentage of all trait words

\begin{tabular}{|c|c|c|c|c|c|c|}
\hline Party & $\begin{array}{l}\text { "Competence" } \\
\text { words }\end{array}$ & $\begin{array}{l}\text { "Excitement" } \\
\text { words }\end{array}$ & $\begin{array}{l}\text { "Rugged" } \\
\text { words }\end{array}$ & $\begin{array}{l}\text { "Sincerity" } \\
\text { words }\end{array}$ & $\begin{array}{l}\text { "Sophistication" } \\
\text { words }\end{array}$ & $\begin{array}{l}\text { As \% } \\
\text { of } \\
\text { total } \\
\text { word } \\
\text { count }\end{array}$ \\
\hline Conservative & $30.25 \%$ & $27.53 \%$ & $11.09 \%$ & $20.96 \%$ & $10.18 \%$ & $0.81 \%$ \\
\hline Labour & $29.13 \%$ & $33.14 \%$ & $11.31 \%$ & $21.33 \%$ & $5.09 \%$ & $0.73 \%$ \\
\hline $\begin{array}{l}\text { Liberal } \\
\text { Democrat }\end{array}$ & $33.17 \%$ & $34.55 \%$ & $4.88 \%$ & $16.42 \%$ & $10.98 \%$ & $0.53 \%$ \\
\hline UKIP & $20.22 \%$ & $29.99 \%$ & $7.06 \%$ & $35.24 \%$ & $7.48 \%$ & $0.91 \%$ \\
\hline Green & $31.53 \%$ & $25.68 \%$ & $11.26 \%$ & $25.45 \%$ & $6.08 \%$ & $0.72 \%$ \\
\hline
\end{tabular}

Third, we carried out multiple correspondence analysis on the word counts shown in Table 2(a). We used multiple correspondence analysis to reduce the complexity shown in that table. Although it is possible to identify certain distinctive patterns in the table, it is easier to understand and to represent these patterns if they can be reduced to fewer dimensions and displayed visually. We use multiple correspondence analysis rather than other methods of data reduction because it respects the nature of the data, and in particular the fact that the entries in the table are count data rather than continuous measures.

To reduce multivariate data to a manageable and interpretable number of variables, a twodimensional MCA solution was used to interpret the five dimensions of brand personality over a 
two dimensional axis (Hoffman and Franke 1986). Using two dimensions is appropriate given the high proportion of variance explained by the first two eigenvectors $(81.4+12.8 \%=94.2 \%)$. As a large amount of textual content yielded a high number of brand personality words, MCA provided a method where interpretation is possible by expressing the relative frequencies of the respective word totals (Greenacre 2010). A two-dimensional model thus aids interpretability and eliminates problems related to inter-spatial differences (Hoffman and Franke 1986, Greenacre 2010).

Fourth, we calculated boot-strapped two dimensional 95\% confidence intervals for these estimates, as suggested by Markus and Visser (1992). We calculated these intervals by simulating data drawn from a multinomial distribution with probabilities equal to the observed probabilities of words in each of the five brand personality categories. We then projected 1000 simulated data sets into the space of the existing MCA solution.

The results of this analysis are plotted in Figure 1(a) and Figure 1(b).

Figure 1(a) plots the positions of the parties, indicated by the position of the text label, and the twodimensional $95 \%$ confidence intervals surrounding these positions. The two dimensions in Figure 1(a) are composites and the result of reducing five traits to two dimensions. Correspondingly, Figure 1(b) plots the positions of these traits along the same two dimensions. Positions are indicated by the position of the text label, and once again two-dimensional $95 \%$ confidence intervals surround these positions. The positions of the parties are added in brackets for ease of reference. 
Figure 1(a): Party positions

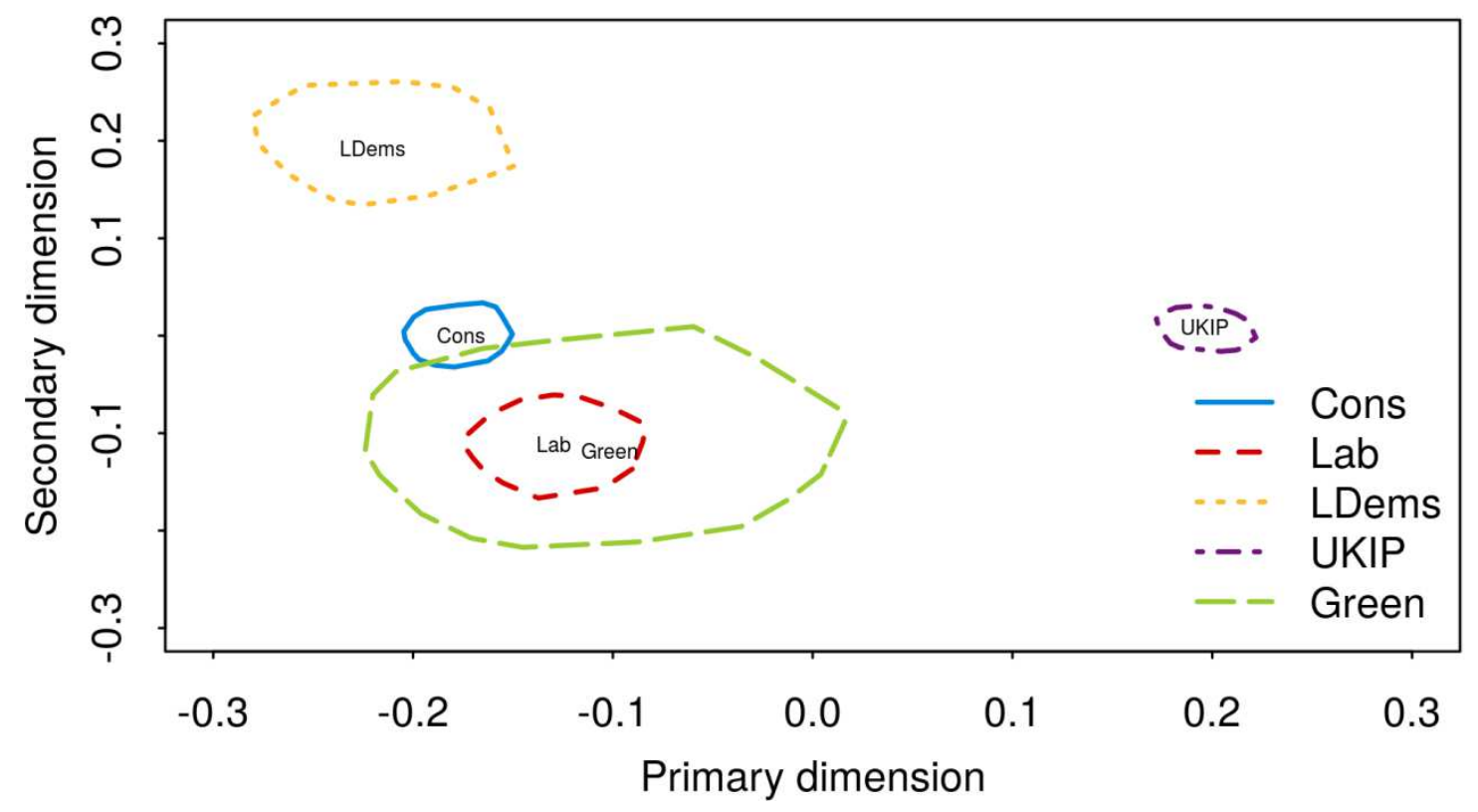


Figure 1(b): Trait positions

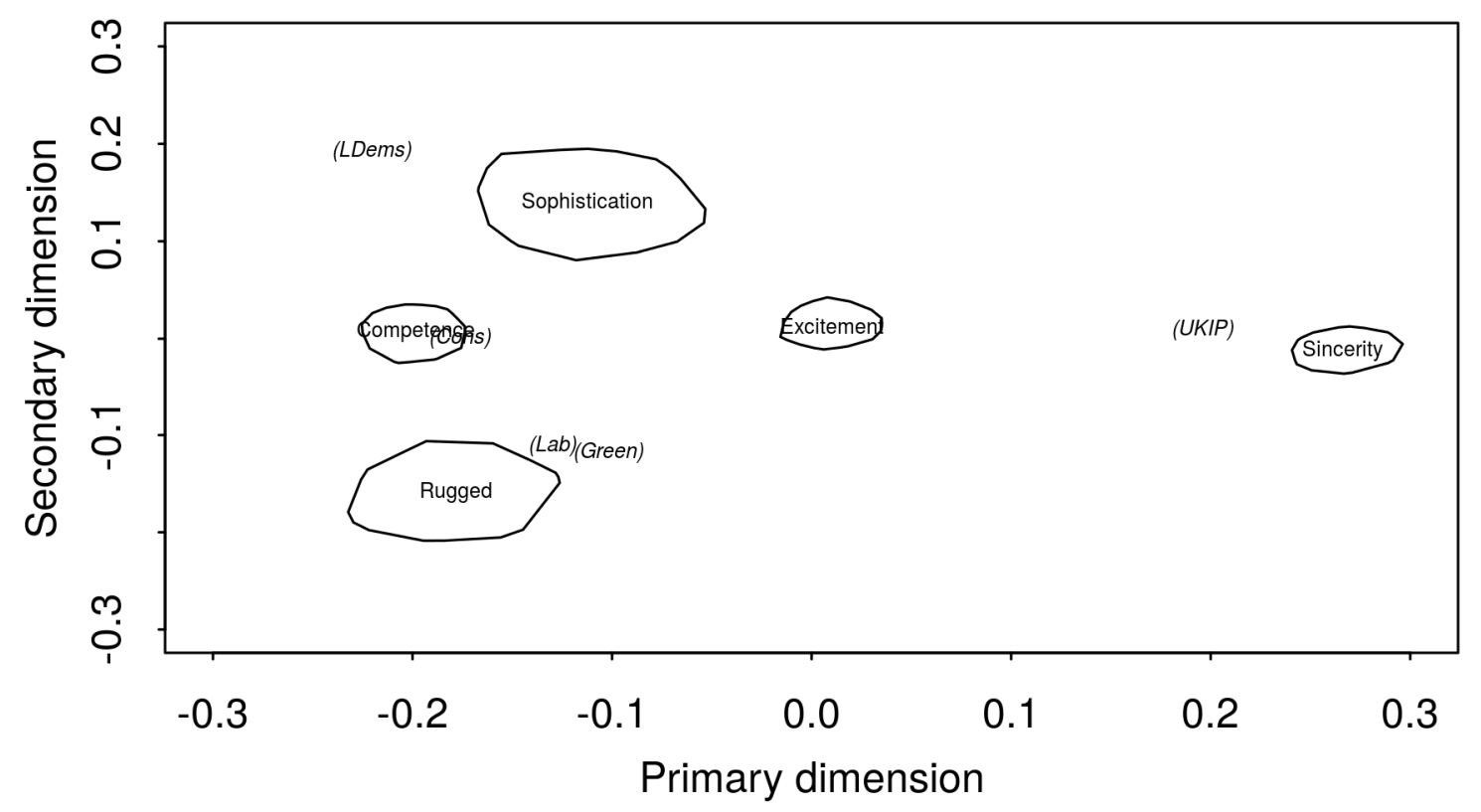

Figure 1(b) shows that the trait "Sincerity" lies to the right of the recovered space. Conversely, the trait "Competence" lies to the left of the recovered space, with "Excitement" in between. Thus, we can interpret the horizontal axis in Figure 1(a) as if it separated more "competent" from more "sincere" parties. Similarly, we can interpret the vertical axis in Figure 1(a) as if it separated more "rugged" from more "sophisticated" parties.

\section{Results and Interpretations}

Having described the procedures we used to analyse our data, we are now in a position to interpret our findings. We begin by discussing the personality traits, before moving on to discuss the revealed positions of the parties.

\section{Brand personality traits}

The plot in Figure 1(b) shows two fundamental tensions: a tension between sincerity and competence, and a tension between sophistication and ruggedness. The first of these tensions is more important, since it corresponds to the first dimension, which explained more of the variation in brand personality-related word usage. The remaining brand personality trait, excitement, ends up 
centrally located in the plot, and does not help in distinguishing between parties. Notwithstanding this, there is no indication of any overlap in the positions of these traits.

\section{The parties}

Considering the parties, Figure 1(b) shows that:

- the Conservative Party communicate Competence strongly, and are positioned between Sophistication and Ruggedness;

- the Liberal Democrats are communicating Competence and Sophistication relatively weakly;

- the Labour and the Green Party communicate both Competence and Ruggedness strongly, although Labour communicate slightly stronger Competence and the Green Party communicate slightly stronger Ruggedness;

- UKIP communicate the direct opposite of other parties on the right hand side and communicate Sincerity strongly and Excitement moderately.

Concerning the degree of uncertainty present in these estimates, revealed by the boot-strapped confidence intervals, we can see that four of the five parties have distinctive brand personalities, with the exception of the Green party, which communicates a brand personality which cannot be distinguished from either the Conservative party or the Labour party, though it is closer to the latter.

These positions make sense given what we know about these five parties and their position within the political system. The Conservative party projects competence strongly, as befits the largest governing party. Although much has been written about David Cameron's attempts to rebrand the party, most commentators have discussed Cameron's efforts to make the party appear less socially illiberal and more in tune with social contemporary mores (Bale 2008). However, an emphasis on competence, and in particular economic competence, has been important both for the party in opposition, criticising the Labour government for its alleged mismanagement of the 2008 financial 
crisis and subsequent recession, and for the party in government, justifying fiscal austerity on the basis that economic competence requires such policies (Gamble 2014). This can be seen in some of the text used on the website. Their website uses phraseology such as "you can show, by how you act and by what you say, that you are competent to govern" and "competence is built on [economic] discipline". In their narrative, they provide a political and economic analysis for the country's future, which Labour were unable to present during their time in office. On their website, they highlight their competence in contrast to the Labour Party Opposition: “we've (...) never known a Government that is so incapable of even the most basic level of competence."

The position of the Labour party reflects their current position in opposition and the current difficulties the party faces in finding a coherent message after Blairism and Brownism. In 1997, New Labour represented Excitement, Sincerity and Sophistication, and this heady brew of potent imagery swept Tony Blair to a massive majority (Driver and Martell 2002). Over the 13 years in which Labour were in power, however, these associations began to break down in the mind of the electorate (Heppell 2008), and Tony Blair's political reputation transference impacted negatively upon the Labour party's brand personality (Davies and Mian 2010). This left Gordon Brown to fall back on his personal attributes of (economic) competence and ruggedness (Baines et al. 2014). The findings of this study show that the Labour party is currently positioned between the brand personality dimensions Competence and Ruggedness, indicating Gordon Brown's personification was transferred to the party brand, and they are still communicating this personality strongly through their website. Some of the words associated with ruggedness are highlighted in the quotes from their website, such as "helping hard working people and families". They also highlighted their propensity for "leading the world in setting tough targets" and "taking tough action" describing themselves as "people who will stand up for a prosperous, fair and democratic Britain" and helping "those who were most vulnerable; those who faced the greatest struggle". However, because of the perceived mismanagement of the economic crisis, the Labour party's image of competence has been undermined (Theakston 2011). Current leader Ed Miliband has since failed to 
recapture the mood of the late 1990s, and the Labour party continues to struggle with a lack of electoral momentum. Within the context of this loss of (perceived) competence, the Labour party are still communicating Competence strongly through their website, perhaps in an attempt to repair the damage caused by the economic crisis. The Ruggedness dimension is also relatively strong, but this may be a residue of Gordon Brown's political influence.

The position of the Liberal Democrats is surrounded by greater uncertainty than any other party with the exception of the Green party. The party as a whole is facing a difficult environment. The party managed to communicate excitement and sophistication in the run up to the 2010 general election, partly as a result of televised election debates featuring the party's leader, Nick Clegg. That sense of novelty continued over to the early months of the Conservative-Liberal Democrat coalition. However, the party's vote share has halved following the abandonment of certain manifesto pledges, and considerable unease concerning the government's fiscal austerity. As a result, it has been unable fully to lay claim to economic competence, and the party's websites seems mostly to communicate the greater access that participation in government has given Liberal Democrat MPs. On their website, they invite guests to an "exclusive drinks reception [..] hosted by the Business Secretary Vince Cable MP [and] joined by senior parliamentarians, leaders in Business and other VIPs.” and to this end, they emphasise their connection with the House of Lords, mentioning Lords no less than 168 times.

The position of the United Kingdom Independence Party is the most distinctive. This is consistent with the party's populist character (Abedi and Lundberg 2009), and in particular the juxtaposition between the hard-working British people on the one hand, and those who have failed them, including Brussels "Eurocrats," but also extending to "career politicians". Given this populist character, "sincerity" acquires much greater importance than technical competence. Sincerity in this instance is communicated through reference to "common sense solutions" to common problems, and "full and frank debate". They also use their website to explain that unlike them, other parties are "out of touch with ordinary people", for instance voters want "proper control over the United 
Kingdom's borders" and politicians to deliver policies which are "realistic and balanced". In short, UKIP is described as "not left, not right, just straightforward".

The position of the Green party is the least well-defined, in that it is surrounded by considerable uncertainty. In certain senses, this is merely a function of the limited size of the Green corpus. Nevertheless, the trait which is predominantly communicated - Ruggedness - matches the party's obvious attention to environmental issues. For example, their website describes "fragile wild spaces and vital farmland", highlighting that there are "many species of animals and plants that are struggling to survive". The party is either unwilling or unable to communicate sincerity in the same way as UKIP: their website emphasises the need to "take bold, responsible and scientifically credible action to avoid catastrophic climate change" and "by making polluters pay, a prosperous and resilient Green economy".

It is difficult to relate the traits that parties to communicate to the positions of parties within the British party system. Although the extent to which UKIP communicates sincerity matches its position as an outsider party, the same is not true of the Green Party, which has sometimes been described as a left-libertarian analogue to UKIP. Although one of the governing parties (the Conservatives) communicates competence very clearly, the Liberal Democrats, also in government, do not communicate competence more than the main opposition party, Labour.

It is possible, however, to identify some potential issues that might arise in the strategic selection of traits to communicate. As we have already noted, it is difficult strategically to communicate sincerity, a trait often linked positively to authenticity and negatively to professionalisation. As such, UKIP may face difficulties in communicating sincerity as effectively as it currently does, if it continues in its efforts to professionalize its campaign operations in the run up to the 2015 general election (shown in the recruitment of journalists from the Daily Express and the BBC). ${ }^{3}$

3 Haroon Siddique, "UKIP recruits BBC's 'Gobby' as communications director", The Guardian, $7^{\text {th }}$ December 2014. 
Equally, however, competence as a trait is only worth signalling if the electorate places high importance on competence vis-à-vis other traits. The Conservative party has been told by one of its strategists, Jim Messina, ${ }^{4}$ that it should focus relentlessly on signalling economic competence; but this message has been jeopardized by the salience of immigration, an issue which relates in part to competence but also in part to a sense of cultural threat.

\section{Conclusion}

In this article, we apply a particular tool used for the analysis of brand personalities to the brand personalities communicated by five British political parties. This dictionary-based tool allows us to estimate the positions of the parties vis-à-vis selected brand personality traits (Sincerity, Competence, Ruggedness, Sophistication and Excitement) in a principled fashion which allows us also to indicate the degree of uncertainty surrounding each party's position. We find that the two main dimensions on which parties' brand personalities differ relate to the trade-offs between communicating Competence and communicating Sincerity, and between communicating Sophistication and communicating Ruggedness. We find that parties' brand personalities are distinctive, with the exception of the Green party, and that the position of one party -- the United Kingdom Independence Party -- is particularly distinctive.

Our research uses Aaker's (1997) existing framework for thinking about brand personalities, rather than creating a new framework for thinking about brand personalities specifically in politics. By using an existing framework, we are able to use tools developed in other disciplines, and illustrate their usefulness for the study of political marketing. We suggest that the benefits of this tool far outweigh the potential costs implied by not tailoring our framework to a specific domain. Readers who believe Smith's (2009) argument, that Aaker's five main traits must be reconfigured before being applied to political parties, generalizes beyond the UK will either have to create custom word-

4 Rachel Sylvester, “The coalition is deeply divided on tax and spend”, The Times, $2^{\text {nd }}$ December 2014. 
lists to apply the method used here, or continue to study the perception of brand personality by random or purposive samples of respondents.

A party's brand personality is formed through the interaction between the electorate, the party leader, the party and its policies (Lees-Marshment 2014), and research overall does suggest exercising caution when using corporate brand management tools in the political arena. Political party brand personalities can be more reliant on leader personality than for business brands.

Likewise, traits of the party may reflect back to the party leader. Not all dimensions of personality will be given equal importance for politics, with additional emphasis tending to be placed on the dimension of Competence (Guzmán and Sierra 2009). Ruling parties or more established parties may also find it more difficult to manoeuvre their personality (Cosgrove 2012).

The method we have used considers only lexical analysis and thus overlooks other aspects that contribute to brand personality, such as the use of colour and imagery on the websites and overlooks the influence of the leader's personality. The analysis does not include stakeholder or electorate perceptions of the brand personality, which would help to further validate the results. A final limitation is based on the deductions drawn from the correspondence analysis of the data. Distances between row and column positions cannot be precisely interpreted, as they are scaled independently. As a result, a political party website positioned close to a certain brand personality dimension may be incorrectly assumed to be very closely related to it.

Despite some of these limitations, our use of a dictionary-based tool opens up exciting new possibilities for the study of brand personality in politics. First, it allows parties to gauge the degree to which their written text do in fact communicate a certain kind of brand personality. Communications experts within the major parties are likely already to be aware (perhaps in pretheoretical terms) of the type of brand personality communicated by the party, but the same may not be true of smaller parties. This approach can support political parties to test that their written communications (on websites and other media) are consistent with the brand personalities they are 
building for their parties and leaders. The tool can also assess the consistency of brand personality being communicated across different textual media, including printed brochures, websites and textbased social media channels (Rutter, Lettice, and Barnes 2013). Where inconsistencies are identified, these can be reviewed and better aligned to the brand personality that the party wishes to convey.

Second, it allows researchers a chance to assess whether the communication of brand personalities affects, or is affected by, the perception of those brand personalities. Our analysis has been based on an extended snapshot of parties' communication via their websites, but the great advantage of a dictionary-based approach is that in principle it allows researchers to generate changing estimates of parties' brand personalities over time. By creating measures which change over time, and matching these measures to measures of party perceived competence, there is the potential to assess the impact of brand personality in a more longitudinal and fine-grained way. It will also enable more thorough comparisons between what is being communicated by a party and what is perceived by the voters reading the text. Extending research to include both the written text analysis and voters' perceptions based on what they have read will add to the understanding of whether communications are perceived as intended and where inconsistencies exist. Although this line of research is likely to be bedevilled by the same problems of reciprocal causation that plague research into media effects, it is clearly an important area for future research.

Finally, just as our use of a dictionary-based tool allows us to explore more variation over time, it also allows us to explore increased variation between parties. Most of the political branding literature has concentrated on parties which have chosen to de-emphasise programmatic appeal and become catch-all parties competing largely on the basis of valence politics. Indeed, when using human raters, concentration on a limited number of parties is necessary to avoid rater fatigue (though this can sometimes be avoided with the use of split-sample surveys: see Nielsen and Larsen (2014)). However, with an automated tool such as that used in this research, estimates of brand personality can be produced for multiple parties within a system, across multiple textual media and 
including parties with strong programmatic appeal. In this way the constraints imposed on brand personalities by strong programmatic appeal can be further investigated. A more thorough analysis of the differences and similarities in communications and between a range of parties can also be achieved. 


\section{References}

Aaker, J. L. 1997. "Dimensions of brand personality." Journal of marketing research no. 34 (3):347-356.

Abedi, Amir, and Thomas Carl Lundberg. 2009. "Doomed to failure? UKIP and the organisational challenges facing right-wing populist anti-political establishment parties." Parliamentary Affairs no. 62 (1):72-87.

Azoulay, A., and J. N. Kapferer. 2003. "Do brand personality scales really measure brand personality?" The Journal of Brand Management no. 11 (2):143-155.

Baines, Paul, Ian Crawford, Nicholas O’Shaughnessy, Robert Worcester, and Roger Mortimore. 2014. "Positioning in political marketing: How semiotic analysis adds value to traditional survey approaches." Journal of Marketing Management no. 30 (1-2):172-200.

Bale, Tim. 2008. "'A Bit Less Bunny-Hugging and a Bit More Bunny-Boiling’\&quest; Qualifying Conservative Party Change under David Cameron." British Politics no. 3 (3):270-299.

Benn, Tony. 1994. Years of Hope: Diaries, Letters and Papers 1940-1962. London: Hutchison.

Benn, Tony. 2002. Free At Last: Diaries 1991-2001. London: Hutchison.

Birdwell, A.E. 1968. "A study of the influence of image congruence on consumer choice." The Journal of Business no. 41 (1):76-88.

Bosnjak, M, V Bochmann, and T Hufschmidt. 2007. "Dimensions of Brand Personality Attributions: A Person-Centric Aproach in the German Cultural Context." Social Behavior and Personality: an international journal no. 35 (3):303-316.

Budge, Ian. 2001. Mapping policy preferences: estimates for parties, electors, and governments, 1945-1998. Vol. 1: Oxford University Press.

Christodoulides, G, L de Chernatony, O Furrer, E Shiu, and T Abimbola. 2006. "Conceptualising and measuring the equity of online brands." Journal of Marketing Management no. 22 (7):799-825. 
Clarke, Harold, David Sanders, Marianne Stewart, and Paul Whiteley. 2011. "Valence politics and electoral choice in Britain, 2010." Journal of Elections, Public Opinion and Parties no. 21 (2):237-253.

Clemenz, Julian, Malte Brettel, and Timo Moeller. 2012. "How the personality of a brand impacts the perception of different dimensions of quality." Journal of Brand Management no. 20 (1):52-64.

Cosgrove, Kenneth M. 2012. "Political branding in the modern age: Effective strategies, tools and techniques." Routledge handbook of political marketing:107-123.

Davies, Gary, and Takir Mian. 2010. "The reputation of the party leader and of the party being led." European Journal of Marketing no. 44 (3/4):331-350.

Dolich, I.J. 1969. "Congruence relationships between self images and product brands." Journal of Marketing Research:80-84.

Downs, Anthony. 1957. An economic theory of democracy: Harper and Row.

Driver, Stephen, and Luke Martell. 2002. Blair's Britain: Polity.

French, Alan, and Gareth Smith. 2010. "Measuring political brand equity: A consumer oriented approach." European Journal of Marketing no. 44 (3/4):460-477.

Gabel, Matthew J, and John D Huber. 2000. "Putting parties in their place: Inferring party left-right ideological positions from party manifestos data." American Journal of Political Science:94103.

Gamble, Andrew. 2014. "Austerity as Statecraft." Parliamentary Affairs:In print.

Garzia, Diego. 2013. "Can Candidates' Image Win Elections? A Counterfactual Assessment of Leader Effects in the Second Italian Republic." Journal of Political Marketing no. 12 (4):348-361.

Geuens, M, B Weijters, and K De Wulf. 2009. "A new measure of brand personality." International Journal of Research in Marketing no. 26 (2):97-107. 
Gibson, Rachel, and Stephen Ward. 2000. "A proposed methodology for studying the function and effectiveness of party and candidate web sites." Social Science Computer Review no. 18 (3):301-319.

Greenacre, Michael. 2010. Correspondence analysis in practice: Chapman and Hall/CRC.

Guzmán, Francisco, and Vicenta Sierra. 2009. "A political candidate's brand image scale: Are political candidates brands\&quest." Journal of Brand Management no. 17 (3):207-217.

Haarhoff, Gareth, and Nicola Kleyn. 2012. "Open source brands and their online brand personality." Journal of Brand Management no. 20 (2):104-114.

Harris, Phil, and Andrew Lock. 1996. "Machiavellian marketing: the development of corporate lobbying in the UK." Journal of Marketing Management no. 12 (4):313-328.

Hayes, Danny. 2005. "Candidate qualities through a partisan lens: A theory of trait ownership." American Journal of Political Science no. 49 (4):908-923.

Heine, K. 2009. "Using personal and online repertory grid methods for the development of a luxury brand personality." Electronic Journal of Business Research Methods no. 7 (1):25-38.

Heinze, Aleksej, and Gordon Fletcher. 2011. Can we make higher education relevant to the needs of the Search \& Social Media Marketing industry? In 6th Education in a Changing Environment Conference, Creativity and Engagement in Higher Education. Salford, Greater Manchester.

Heppell, Timothy. 2008. "The Degenerative Tendencies of Long-Serving Governments... 1963... 1996... 2008?" Parliamentary Affairs no. 61 (4):578-596.

Hoffman, Donna L, and George R Franke. 1986. "Correspondence analysis: graphical representation of categorical data in marketing research." Journal of marketing research:213-227.

Jamal, A., and M.M.H. Goode. 2001. "Consumers and brands: a study of the impact of self-image congruence on brand preference and satisfaction." Marketing Intelligence \& Planning no. 19 (7):482-492. 
Karlsen, Rune. 2010. "Online and undecided: Voters and the Internet in the contemporary Norwegian election campaign." Scandinavian Political Studies no. 33 (1):28-50.

Katz, Richard S, and Peter Mair. 1995. "Changing models of party organization and party democracy the emergence of the cartel party." Party politics no. 1 (1):5-28.

Kuenzel, S., Phairor, KH. 2009. A Short scale for Measuring brand personality. In Australian and New Zealand Marketing Academy conference.

Lee, J., G. Soutar, and V. Quintal. 2010. Destination Personality: Cross-Country Comparisons. In Proceedings of Australian and New Zealand Marketing Academy conference.

Lees-Marshment, J. 2014. Political Marketing 2nd Edition: Principles and Applications: Taylor \& Francis.

Malhotra, N.K. 1981. "A scale to measure self-concepts, person concepts, and product concepts." Journal of Marketing Research:456-464.

Markus, Monica Th, and Ron A Visser. 1992. "Applying the bootstrap to generate confidence regions in multiple correspondence analysis." In Bootstrapping and Related Techniques, 7175. Springer.

Mattes, Kyle, and Caitlin Milazzo. 2014. "Pretty faces, marginal races: Predicting election outcomes using trait assessments of British parliamentary candidates." Electoral Studies no. 34:177-189.

Nielsen, Sigge, and Martin Larsen. 2014. "Party brands and voting." Electoral Studies no. 33:153165.

Norris, Pippa. 2003. "Preaching to the converted? Pluralism, participation and party websites." Party Politics no. 9 (1):21-45.

Opoku, R. 2006. Towards a methodological design for evaluating online brand positioning, Industrial Marketing and e-Commerce Research Group, Luleå University of Technology. 
Opoku, R, LF Pitt, M Hultman, R Abratt, and S Spyropoulou. 2007. "What I say about myself: Communication of brand personality by African countries." Tourism Management no. 28 (3):835-844.

Opoku, Robert, Russell Abratt, and Leyland Pitt. 2006. "Communicating brand personality: are the websites doing the talking for the top South African business schools?" Journal of Brand Management no. 14 (1):20-39.

Owens, Ryan J, and Justin P Wedeking. 2011. "Justices and legal clarity: Analyzing the complexity of US supreme court opinions." Law \& Society Review no. 45 (4):1027-1061.

Papagiannidis, Savvas, Constantinos K Coursaris, and Michael Bourlakis. 2012. "Do websites influence the nature of voting intentions? The case of two national elections in Greece." Computers in Human Behavior no. 28 (2):300-307.

Patterson, Anthony, Yusra Khogeer, and Julia Hodgson. 2013. "How to create an influential anthropomorphic mascot: Literary musings on marketing, make-believe, and meerkats." Journal of Marketing Management no. 29 (1-2):69-85.

Popkin, Samuel L. 1994. The reasoning voter: Communication and persuasion in presidential campaigns: University of Chicago Press.

Rutter, RN, F Lettice, and SJ Barnes. 2013. An empirical Study of the Effect of Brand Personality Consistency on Recruitment Performance within the UK Higher Education Sector. Paper read at 8th Global Brand Conference, at Catholic University of Portugal, Porto, Portugal.

Rutter, RN., and F. Lettice. 2014. The Importance of Political Brand Personality Differentiation. Paper read at 9th Global Brand Conference, at University of Hertfordshire, Hertfordshire, UK.

Sääksjärvi, Maria, and Saeed Samiee. 2011. "Relationships among brand identity, brand image and brand preference: differences between cyber and extension retail brands over time." Journal of Interactive Marketing no. 25 (3):169-177. 
Sanders, David, Harold D Clarke, Marianne C Stewart, and Paul Whiteley. 2011. "Downs, stokes and the dynamics of electoral choice." British Journal of Political Science no. 41 (02):287314.

Shephard, Mark, and Robert Johns. 2008. "Candidate image and electoral preference in Britain." British Politics no. 3 (3):324-349.

Sirgy, M.J., D. Grewal, T.F. Mangleburg, J. Park, K.S. Chon, CB Claiborne, JS Johar, and H. Berkman. 1997. "Assessing the predictive validity of two methods of measuring self-image congruence." Journal of the Academy of Marketing Science no. 25 (3):229-241.

Sirgy, M.J., and C. Su. 2000. "Destination image, self-congruity, and travel behavior: Toward an integrative model." Journal of Travel Research no. 38 (4):340-352.

Slapin, Jonathan B, and Sven - Oliver Proksch. 2008. "A scaling model for estimating time - series party positions from texts." American Journal of Political Science no. 52 (3):705-722.

Slatcher, Richard B, Cindy K Chung, James W Pennebaker, and Lori D Stone. 2007. "Winning words: Individual differences in linguistic style among US presidential and vice presidential candidates." Journal of Research in Personality no. 41 (1):63-75.

Smith, Gareth. 2001. "The 2001 general election: Factors influencing the brand image of political parties and their leaders." Journal of Marketing Management no. 17 (9-10):989-1006.

Smith, Gareth. 2009. "Conceptualizing and testing brand personality in British politics." Journal of political marketing no. 8 (3):209-232.

Smith, Gareth, and John Saunders. 1990. "The application of marketing to British politics." Journal of Marketing Management no. 5 (3):295-306.

Stokes, Donald E. 1963. "Spatial models of party competition." The American Political Science Review:368-377.

Sweeney, J.C., and C. Brandon. 2006. "Brand personality: Exploring the potential to move from factor analytical to circumplex models." Psychology and Marketing no. 23 (8):639-663. 
Theakston, Kevin. 2011. "Gordon Brown as prime minister: Political skills and leadership style." British Politics no. 6 (1):78-100.

Urde, Mats. 1999. "Brand orientation: a mindset for building brands into strategic resources." Journal of marketing management no. 15 (1-3):117-133.

Ward, M. R., and M. J. Lee. 2000. "Internet shopping, consumer search and product branding." Journal of Product \& Brand Management no. 9 (1):6-20.

White, Jon, and Leslie De Chernatony. 2002. "New Labour: A study of the creation, development and demise of a political brand." Journal of Political Marketing no. 1 (2-3):45-52. 